Information Management and Business Review

Vol. 4, No. 11, pp. 563-569, Nov 2012 (ISSN 2220-3796)

\title{
Organizational Environment Research: Methodology Proposed to a Higher Education Institution from Serra Gaucha
}

\author{
Juliana Raquel de Souza Luchesi, Kelly Menezes Crespi, Maria Emilia Camargo* \\ University of Caxias do Sul, Caxias do Sul, RS, Brazil \\ *kamargo@terra.com.br
}

\begin{abstract}
The people who form them differentiate the organizations and it is because of that the competitiveness is fierce nowadays. The environment organization research is a formal method to evaluate the environment of a company and it is an important instrument to provide subsidies, which allow the constant improvement of the work environment. Therefore, we propose the study of the organizational environment through the construction of a research instrument applied to the teachers of the Department of Administration from a Higher Institution at Serra Gaucha. The objective is to identify the aspects related to the commitment in the accomplishment of the job and the improvement on the quality of the provided services and to verify if the punctuation of the factors diverges. After the application of the questionnaire, we can observe that the mean values of the opinion regarding the categories (Institutional Image, Institutional Politics, System of Assistance and Benefits, Organization Structure, Organization and Work Condition, Interpersonal Relationship, Leadership Behavior, Personal Satisfaction, Institutional Planning, Decisive Process, University Autonomy and Institutional Evaluation) of respondents is good, because the averages are, in most cases, above the value 3 (the scale ranges from 1 to 5). The one that had an average below 3 was referred to the decision process. The mean general was 3.6. We can observe that the mean values of the opinion regarding the categories of respondents are good, because the averages are, in most cases, above the value 3 (the scale ranges from 1 to 5). The one that had an average below 3 was referred to the decision process. The mean general of respondents was 3.6.
\end{abstract}

Keywords: organizational environment; organizational culture; motivation; higher education institution

\section{Introduction}

One of the education institutions compromise is to foment the man's evolutional questioning and his interaction with the environment in all its dimensions. As in all companies, people are responsible for the quality of the services or the consumer goods offered to the market largely, it is on the teacher to offer the quality to the academics. It is important to analyze the motivation and the perception of these professionals developing their activities so the organizational environment research is an effective tool to this end. In this meaning, it is important to reinforce that the organizational environment is the product of many sets of motivational aspects correlated, mainly, in attitudes and behaviors. Therefore, the study of the organizational environment is a potentially strong instrument to the improvement of the quality in the organizations. Therefore, we propose the study of the organizational environment, through the construction of a research instrument applied to the faculty of the Department of Administration of a College institution at Serra Gaucha. The objective is to identify the aspects related to the compromise when accomplishing the job and the improvement of the services provides.

\section{Theoretical Fundamentation}

Motivation: The motivation to work is a psychological state of disposition, interest or the will of pursuing and accomplishing a task or goal. This motivation is the result of a complex interaction among the people's internal reasons and the stimulus of the situation or the environment. There are internal reasons such as needs, abilities, interests, values and people's abilities. These reasons individualize each people and make different. There are also the external reasons, which are the stimulus the company offers. They can satisfy needs, awaken feelings of interest or represent a desired gratification. The salary and the benefits, the coworkers and the leading style of the boss are the aspects considered in this category (Maximiano, 2006). To 
Robbins (2005) motivation is the process responsible for the intensity, direction and persistency of the efforts from a person to achieve a specific goal, although the motivation, in general, is related to the effort to accomplish any objective. Next, we follow with Griffin (2007) thought which concepts motivation in a wider way, stating that motivation is a set of strengths, which lead people to behave in a certain manner. The individual performance is usually determined by three factors: motivation (desire of working), ability (capability of working) and work environment (the resources necessary to work). The current scenery faced by the companies shows that the motivational focus implies in an internal stimulus able to create a positive mental attitude or a change in attitude - self-motivation - with permanent effects. Therefore, the basic definition of motivation would be to provide the people their own reasons to action, which will always be internal and deeply convicted. It is prudent and useful to look again to the attempting of understanding of the human being in its totality (Palominos, 1997).

Frustration: The frustration cause different kind of behavior in the work environment according to the author Maximiano (2006):

a) escaping or compensation: the search for another job or profession when there is no possibility of progress at the current job; professional association or syndicate to defend interests which are not supplied by the employer;

b) Resignation: occurs when a group or a person leaves down by frustration and surrender to a State of discouragement or fatality. The person surrenders. Resignation in the workplace is manifested through the depression, apathy and disinterest by the company and its objectives;

c) Aggression: represents some way of verbal or physical attack, associated to a feeling of anger and hostility. It could be a bad word, a kick on the wall or throwing a tool into a gear. In this case it could also be adopted a displacement behavior.

Organizational Culture: Wagner III and Hollenbeck (2003) address the concept of organizational culture as an informal and sharing way of perceiving life and the participation in the organization, which keeps its member, joined and influence what they think about themselves and their job. In the process of helping to create a mutual understanding of the life in the organization, the organizational culture develops four basic functions: to give an organizational identity to the members, make the group commitment easy, promote the organizational stability and shapes the behavior while helps the member give a sense to their environment. Many forces shape the culture of a company. Frequently the origin is in the values, in the administrative practices and in the personality of the founder or founders. The leader's vision also puts a strong impact over the culture. The organizational culture responds and reflects on the conscious and unconscious choices, on the behavior patterns and on the prejudgments of the executive managers. It is important to mention the way of learning of the organizational culture, which happens mainly through the socialization. The understanding of the values, rules and essential habits happens in this process. The process of socialization occurs, mainly, through the learning through imitation and observation. Another way, still highlighted, it is through the teachings of the leaders, as implied in the cultural dimension of resources and rewards allocation (Dubrin, 2003). Composing the concept of culture the author Mintzberg (2000) makes an association with the group cognition, representing the vital force, the soul and the physical body of the organization. The more closed the web joining interpretations and activities, the deeper rooted is the culture.

Organizational Environment: To Johann (2004), the organizational environment is made by the amount of the influence of factors as different as salary, relationship and communication between the leadership and the employers, medical insurance, health conditions, recognition (or its lack). These and other aspects can offer a vision of the emotional state of the organization and of the impact or receptivity the intervention will have on this environment, enabling the adjustment of the individual and collective needs, although there is a lack in programs searching express and deliberate changes highlighted on this state of the things. Bergamini and Coda (1997) characterizes the Organizational Environment Research as a communication channel between the directors and the employees of the organization, it represents a constant way of receiving feedback, keeping the focus turned to the employees' needs. It gives orientation and democratization to the employees' participation in the process of managing, once the decisions also include the employee's tendencies and points of view manifested through the research. The model of Litwin and Stinger (1968) refers to the empirical study to measure the environment through the structure, responsibility, risks, rewards, hit and support and conflict. The research of Kolb et al. (1978) discusses the organizational climate in a scale of seven 
factors: conformity, responsibility, standards, rewards, organizational clarity, warmth, support, and leadership. From the point of view of author Sbragia (1983), the research must be wider. Its model counts on twenty factors, considering relevant: state of tension, conformity demanded, emphasis on the participation, proximity of the supervision, human consideration, structure adequation, present autonomy, proportional rewards, prestige obtained, existing cooperation, emphasized patterns, attitude facing conflicts, identity feelings, logistic support proportioned, recognition proportioned and way of controlling.

Related to Rizzatti's model (1995) a model was offered which was applied in a federal university, considering the following aspects: image and evaluation, human resources development, benefits and incentive, work organization and condition, interpersonal relationship, politics-administrative succession and leadership behavior and personal satisfaction. Rizzatti (2002) deepened the proposed studies in 1995, with the insertion of new categories to be considered in an organizational environment research in education institutions, which covers: institutional image, human resources politics, system of assistance and benefits, organizational structure, organization and work conditions, interpersonal relationship, leadership behavior, personal satisfaction, institutional planning, decisive process, university autonomy and institutional evaluation. The environment research doesn't proposes itself to solve all the internal problems of a company, the same way that a research about the satisfaction of the external client doesn't make sure the success of a company related to its contestants. So, the company that decides to make an environmental action-research, the high directors must be aware of the risks which may occur, among them we have: the lack of commitment with the improvement of the deficient aspects mentioned before what ends up leading to more dissatisfaction, deception about the results, especially with the low receptivity on the changes proposed, the growth of fake expectations of the employees, inappropriate communication during all of the steps and discontinuity of the process (Johann, 2004). The company that decides to make an environmental action-research, the high directors must be aware of the risks, which may occur (Johann, 2004). Among of the risks we have: the lack of commitment with the improvement of the deficient aspects mentioned before what ends up leading to more dissatisfaction, deception about the results, especially with the low receptivity on the changes proposed, the growth of fake expectations of the employees, inappropriate communication during all of the steps and discontinuity of the process (Johann, 2004).

\section{Methodology}

According to Churchill Jr. and Peter (2000), the primary data are those collected specifically to the purpose of the investigation. The primary data are those collected specifically to the purpose of the investigation (Churchill Jr and Peter, 2000). Hair Jr. et al. (2005) complement the thought when stating that, under the context of a research with primary data, the researcher is involved in all the aspects of the transformation of data in knowledge, when, any research project, which demands the creation and implementation of a survey, will originate the primary data. Because of its characteristics, this proposal of organizational environment research, to be structured to the application in the Department of Administration of a Higher Institution at Serra Gaucha, will count on the kinds of primary data. The research counted on a qualitative phase when occurred the data collect and an instrument was structured, directed to the capitation of the feedback of experts in this areas of organizational behavior so the chosen model would be the base to the construction of the questionnaire of organizational environment to be used. The step consisted in the brief explanation of the purposes of the study and after the presentation of the attributes of the studies of the authors Litwin and Stinger, Kolb et al., Sbragia, and Rizzatti. Each teacher consulted indentified one of the models and justified the choice from their knowledge and judgment of the applicability and coherence. On the Figure 1, we can observe the results obtained in this step of the research and Figure 2 is the justification of the choice of models. The survey counted with a qualitative phase to the abstraction of the opinion all teachers who teach the discipline of organizational behavior. Step consisted of brief explanation of the purposes of the study and after the presentation of the attributes of the studies of authors Litwin and Stinger (1968), Kolb et al. (1978), Sbragia (1983), Rizzatti (2002) and Martins (2000). Each teacher consulted identified models and justified the choice from their knowledge and judgment of applicability and coherence. In Figure 1, you can see the results at this stage of research. In addition, Figure 2 is the justification of the choice of models. 
Figure 1: The choice of the experts about the kind of study to be performed - Qualitative Phase

\begin{tabular}{|c|c|c|c|c|}
\hline & Prof. A & Prof. C & Prof. D Prof. E \\
\hline $\begin{array}{l}\text { Model I: } \\
\text { Litwin and Stinge } \\
\text { Model II: Kolb et a } \\
\text { Model III: Sbragia } \\
\text { Model IV: Rizzatti }\end{array}$ & $\begin{array}{l}(1968) \\
.(1978) \\
1983) \\
2002) \\
\end{array}$ & XXX & & $\mathrm{XXX}$ \\
\hline \multicolumn{5}{|c|}{ Figure 2: Justification for the choice of the models } \\
\hline Prof. A & Prof. B & Prof. C & Prof. D & Prof. E \\
\hline $\begin{array}{l}\text { "It measures } \\
\text { with most } \\
\text { property, } \\
\text { considering the } \\
\text { kind of person } \\
\text { who will answer } \\
\text { the same } \\
\text { coherence and } \\
\text { applicability". }\end{array}$ & $\begin{array}{l}\text { "Better } \\
\text { application, seeing } \\
\text { the facility that the } \\
\text { teacher would } \\
\text { have } \\
\text { understand it and } \\
\text { answer it. More } \\
\text { applicable to } \\
\text { educational } \\
\text { institutions". }\end{array}$ & $\begin{array}{l}\text { "I understand that } \\
\text { the chosen model } \\
\text { offers more fullness } \\
\text { of information about } \\
\text { the attributes which } \\
\text { influence the } \\
\text { environment of the } \\
\text { Department of } \\
\text { Administration. } \\
\text { Rizzatti's model } \\
\text { seems to direct the } \\
\text { attributes to the } \\
\text { general planning of } \\
\text { the institution, not } \\
\text { necessarily to the } \\
\text { individual feeling of } \\
\text { the teacher". }\end{array}$ & $\begin{array}{l}\text { "The elaborated } \\
\text { model } \\
\text { comprehends } \\
\text { some dimensions } \\
\text { that pervade the } \\
\text { organizational } \\
\text { environment of } \\
\text { the Department of } \\
\text { Administration, } \\
\text { when properly } \\
\text { analyzed and } \\
\text { investigated; they } \\
\text { provide a vision of } \\
\text { the many process } \\
\text { which are } \\
\text { developed in the } \\
\text { organization". }\end{array}$ & $\begin{array}{l}\text { "Considering the } \\
\text { current moment of } \\
\text { the Department of } \\
\text { Administration, this } \\
\text { is the most complete } \\
\text { model. } \\
\text { I suggest that the } \\
\text { way of its } \\
\text { applicability is } \\
\text { analyzed so it won't } \\
\text { come up with } \\
\text { interpretations } \\
\text { about the subject, } \\
\text { once that the } \\
\text { attributes include } \\
\text { manyideas". }\end{array}$ \\
\hline
\end{tabular}

\section{Results and Analysis of Data}

In the quantitative phase of the research, we used a non-probabilistic sample by convenience formed by ten teachers from the Department of Administration from College Institution. The data referent to the profile of the interviewed teachers showed the following results:

a) In reference to the fullness of the teacher - $90 \%$ is related directly to the Department of Administration and $10 \%$ teach business subjects, but it is crowded in another Higher Institution Campi. In reference to the academic formation: $80 \%$ are masters and $20 \%$ are specialists.

b) In reference to the working, time in the College Institution - less than 5 years $-30 \%$, from 5 to 10 years $-0 \%$, from 11 to 15 years $-30 \%$, from 16 to 20 years $-10 \%$ and more than 20 years $-30 \%$. In reference to the gender $-60 \%$ male and $40 \%$ female.

c) In reference to the age - until 30 years - $0 \%$, from 31 to 40 years - $40 \%$, from 41 to 50 years - 30\%, from 51 to 60 years $-20 \%$ and over 60 years $-10 \%$.

d) In reference to the work, shift in the Administration Department - $40 \%$ only at night, $20 \%$ in the evening and at night and $40 \%$ in the morning, in the evening and at night.

e) In reference to the subjects given in the semester -2 subjects $-20 \%, 3$ subjects $-20 \%, 4$ subjects $20 \%, 5$ subjects $-30 \%$ and 6 subjects $-10 \%$. In reference to the research group $-50 \%$ answered Yes and $50 \%$ No.

f) Besides the questions mentioned above, the instrument used to collect data relied with forty questions constituted through Rizzatti's study (2002). The interviewed answered in a regimen measured in a Likert scale $(1=$ minimum and $5=$ maximum).

g) For a descriptive analysis, the mean by category for each question associated to the 10 interviewed was obtained. 
Figure 3: Mean obtained with the answers from the 10 teachers

Researched Categories and Structured Questions Answers

Mean

Institutional Image

Mean $=4.43$

1) I am satisfied about being a part of this department. $\quad 4.80$

2) I perceive the satisfaction. $\quad 3.80$

3) I identify myself with the department, as if with the institution and I wish to 4.40 continue being a part of its development.

4) I am recognized in the society because I work as a teacher in this College 4.70 Institution.

\section{Institutional Politics}

5) The organizational politics allow me to be valued professionally.

6) The organizational politics promote the integration of the teachers.

7) The organizational politics encourage me or awake inside of me the need of a continuous learning.

\section{Benefits and Helping System}

8) The benefits offered by the institution bring quality to the accomplishing of my job.

9) The financial rewards I receive are motivational factors to my job.

10) The qualities of the financial rewards I receive meet my expectations.

\section{Organizational Structure}

11) There an adequacy from the institutional structure to the needs of the Department of Administration.

12) There is a good relationship and communication among the hierarchic levels of the department.

13) The objectives and goals of the department are clear and related with the job I perform.

14) I have good technological conditions available to accomplish my job.

Mean $=3.17$

3.30

2.60

3.60

15) I have total knowledge of the tasks and responsibilities of my job.

\section{Work Condition and Organization}

16) The ergonomic conditions meet to my needs, such as temperature, ventilation, illumination, cleansing and furniture.

17) I have enough time to execute my tasks related to the accomplishment of a good job.

18) I find physical space in the department to accomplish my tasks as a teacher. Interpersonal Relationship

19) I know the existent boss structure and I indentify the role of each one daily.

Mean $=3.43$

3.30

3.30

3.70

Mean $=3.36$

2.50

3.60

3.00

20) There is an intense and active cooperation among the teachers from the Department of Administration.

21) The cooperation existing among the areas, which compound the Department of Administration (secretary, photocopy, safety, laboratories...), is enough.

22) There is recognition to the professional competence among the co-workers.*

23) There is an encouragement among the co-workers to improve the development of the teachers.*

\section{Managers Behavior}

24) I trust and believe in the work performed by the head of the departments and center.

25) The leadership awakens the environment to the teacher's human development.

26) The leadership allows the appropriate resources to the work development.

27) The leadership accepts and applies the suggestions given by the teachers in the Department of Administration.

28) The level of follow-up of the job, performed by the leadership, is adequate.

Personal Satisfaction

29) I am satisfied with the job I perform as a teacher.

3.40

4.30

Mean $=\mathbf{3 . 3 7}$

3.20

3.30

3.60

Mean $=3.24$

4.30

3.10

3.10

3.30

2.80

Mean $=\mathbf{3 . 6 0}$

4.10

3.70

3.80

3.60

2.80

Mean $=4.30$

4.50 
30) I feel myself motivated to teach and with the job conditions, I have.

4.10

31) I know that the responsibility attributed to the teacher/professor job is coherent

4.30

with my intellectual and emotional capacities.

\section{Institutional Planning}

32) I feel myself motivated to participate of the institutional planning

Mean $=3.90$

33) I receive updated information about the plans and institutional pretentions.

3.90

34) I contribute to the improvement of the services provided by the College Institution.

\section{Decision Process}

35) The department decisions, which affect the teacher's job, are passed forward in timely and clear way.

36) The amount of departmental meetings is enough and allows the teachers to keep themselves informed.

37) I notice that there is the prevalence of ideas and interests from some groups of teachers over others in the department.*

University Autonomy

38) I believe that the institutional strategies supply the departmental needs and contributes to the improvement of the quality of services provides in the Department of Administration.

\section{Institutional Evaluation}

39) I notice that the personal values from the learners have influence on the evaluation process of the teachers.

40) The institution evaluation current model identifies the problems in the 2.70 Department of Administration.

*Items with opposite counting.

Observing the mean values can be said that the opinion regarding the categories After the application of the questionnaire, we can observe that the mean values of the opinion regarding the categories (Institutional Image, Institutional Politics, System of Assistance and Benefits, Organization Structure, Organization and Work Condition, Interpersonal Relationship, Leadership Behavior, Personal Satisfaction, Institutional Planning, Decisive Process, University Autonomy and Institutional Evaluation) of respondents is good, because the averages are, in most cases, above the value 3 (the scale ranges from 1 to 5 ). The one that had an average below 3 was referred to the decision process. The mean general was

\section{Conclusion}

To manage so many talents, mainly from the teachers of the College Institution, their motivations and satisfactions, it is necessary to monitor their yearnings and behaviors, because these are the professionals who interact continuously with their pupils, this, clients of the institutions. Subjects like motivation, commitment and frustration in the work environment always denote challenging studies, because of the amplitude and subjectivity in the human actions, but each paragraph constructed from the readings and the studies performed helps to build a new look about the daily, about the importance of human relationships and the value given to the job. Through this study, we created a research instrument about organizational environment directed to the teachers from the Department of Administration from a Higher Institution at Serra Gaucha. We shall conclude through the results of the research, that the instrument is adherent to proposed ending and can be adapted to the application in other departments or College Institution easily. In reference to the context of the researched sample, the teachers are satisfied about being a part of College Institution and of the department where they work. We also found that the interviewed are satisfied with their job as teachers. On the other hand, the teachers pointed out that there is not active and intense cooperation among the teachers and they do not feel motivated to participate of the planning of College Institution. These divergences were proven through the median test, which indicated a significant difference among the researched categories. 


\section{References}

Bergamini C. W. \& Coda R. (1997). Psychodynamics of organizational life: motivation and leadership. 2 th. ed. São Paulo: Atlas.

Churchill, G. A. Jr \& Peter, J. P. (2000). Marketing: criando valor para os clientes. São Paulo: Saraiva, 2ª edição.

Dubrin, A. J. (2003). Fundamentos do comportamento organizacional. São Paulo: Pioneira Thomson Learning. Griffin, R. W. (2007). Introdução à administração. São Paulo: Ática.

Johann, S. L. (2004). Gestão da cultura corporativa: Como as organizações de alto desempenho gerenciam sua cultura organizacional. São Paulo: Saraiva.

Hair, J., Babin, B., Money, A. \& Samouel, P. (2005). Fundamentos de métodos de pesquisa em administração. Porto Alegre: Bookman.

Kolb, D. A., Rubin, I. R. \& Mcintyre, J. M. (1978). Psicologia organizacional: uma abordagem vivencial. São Paulo: Atlas.

Litwin, G. H. \& Stringer, R. A. (1968). Motivation and organizational climate. Cambridge: Harvard University Press.

Maximiano, A. C. A. (2006). Administração para empreendedores: fundamentos da criação e da gestão de novos negócios. São Paulo: Pearson Prentice Hall.

Martins, M. C. F. (2000). Clima organizacional: o estado da arte. Revista da Sociedade de Psicologia do Triângulo Mineiro, 3, 12-18.

Mintzberg, H. (2000). Safári de estratégia: um roteiro pela selva do planejamento estratégico. Porto Alegre: Bookman.

Palominos, R. (1997). Nem acaso, nem milagre: a gestão do compromisso. São Paulo: Editora Gente.

Rizzatti, G. (1995). Análise de fatores significativos do clima organizacional da UFSC: contribuição para implantação do programa de qualidade. Florianópolis. Dissertação (Mestrado). Departamento de Engenharia de Produção e Sistemas, Universidade Federal de Santa Catarina.

Rizzatti, G. (2002). Categorias de análise de clima organizacional em universidades federais brasileiras. Tese (Doutorado em Engenharia de Produção) Programa de pós-graduação em Engenharia de Produção e Sistemas da Universidade Federal de Santa Catarina.

Robbins, S. P. (2005). Comportamento organizacional. 11. ed. São Paulo: Pearson Prentice Hall.

Sbragia, R. (1983). Um estudo empírico sobre clima organizacional em instituições de pesquisa. Revista de Administração, 2(18), 30-9.

Wagner III, J. A. \& Hollenbeck, J. R. (2003). Comportamento organizacional. São Paulo: Saraiva. 